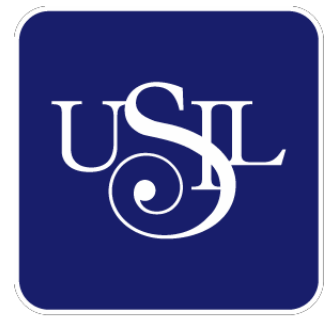

UNIVERSIDAD

SAN IGNACIO

DE LOYOLA

FACULTAD DE HUMANIDADES

Carrera de Psicología

\title{
PROPIEDADES PSICOMÉTRICAS DEL CUESTIONARIO DE CALIDAD DE VIDA QLQ-BR23 EN PACIENTES CON CÁNCER DE MAMA
}

Tesis para optar el Título Profesional de Licenciado en Psicología

ADRIANA SALOME FERNANDA RAMIREZ POLANCO (0000-0001-6317-7530)

\section{ASTRID MONTSERRAT RÚA LIZÁRRAGA}

(0000-0002-9827-9729)

Asesor:

Dr. Sergio Alexis Domínguez Lara

(0000-0002-2083-4278)

Lima - Perú

2020 


\section{Dedicatoria}

A mis padres, quienes siguen siendo inspiración y apoyo para cumplir con todos mis objetivos propuestos en vida. Al equipo de Psicooncología del INEN por su vocación, soporte y docencia durante la experiencia de internado. Y, a todos los pacientes que nos inspiraron y enseñaron cada día.

Adriana Ramirez

A Olga Lizárraga, Marilyn Toledo, Esther Montes, Haydee Oblitas, Norma Reátegui, al equipo de Psicooncología de INEN del año 2019, quienes con su confianza, capacidad, vocación de servicio y docencia me formaron en lo primordial sobre la salud mental. A nuestros pacientes oncológicos y al Club de la Mama de INEN, quienes con su espíritu de lucha fueron la razón de hacer esta investigación.

Astrid Rúa 


\section{Agradecimiento}

A Martha Paredes por ser la voz de mi consciencia. A César Merino por la oportunidad de adentrarme al mundo de la psicometría; y a Sergio Domínguez por explotar nuestro máximo potencial.

Adriana Ramirez

A mi familia, por su infinita paciencia y apoyo a que logre alcanzar mis sueños. A Sergio Domínguez, por su paciencia y sabiduría ejemplar en el campo de la investigación.

Astrid Rúa 


\section{Resumen}

El objetivo del presente estudio fue hallar evidencias de las propiedades psicométricas del Cuestionario de Calidad de Vida - Módulo Cáncer de Mama (QLQ-BR23). La muestra se constituyó por 150 pacientes mujeres con cáncer de mama $(\mathrm{CaM})$ entre 28 a 85 años $(\mathrm{M}=50.40)$ del Instituto Nacional de Enfermedades Neoplásicas. Se halló evidencias de validez vinculadas al contenido por criterio de jueces, y en cuanto a las evidencias de validez con relación estructura interna se optó por el análisis factorial exploratorio (AFE). En cuanto a los resultados asociados a las evidencias de validez de contenido se obtuvo una V de Aiken para relevancia $(V>.95)$ y claridad $(V>.85)$; mediante el procedimiento analítico-factorial se eliminaron 6 ítems $(1,2,4,6,7$ y 8) por presentar complejidad factorial (CF) lo que logró aumentar la varianza total explicada de $53.80 \%$ a $61.61 \%$. La estructura final estuvo conformada por tres factores denominados Perspectiva Corporal (F1), Interés Sexual (F2) y Sintomatología Pre-diagnóstica y Peri-tratamiento (F3). Por último, los coeficientes de confiabilidad Alfa y Omega de las puntuaciones del constructo obtuvieron magnitudes adecuadas (>.70) para los factores de Perspectiva Corporal (F1) y Sintomatología Prediagnóstica y Peri-tratamiento (F3) a excepción del Interés Sexual (F2) con una magnitud aceptable (>.65) mientras que el coeficiente ORION obtuvo una magnitud alta (>.80) para todos los factores. En conclusión, se determinaron evidencias favorables de validez de contenido y de estructura interna del instrumento QLQ-BR23.

Palabras claves: calidad de vida, cáncer de mama, QLQ-BR23, validez, confiabilidad. 


\begin{abstract}
The aim of the present study was to find evidences the psychometric properties of the Quality-of-Life Questionnaire - Breast Cancer Module (QLQ-BR23). The sample was taken from the National Institute of Neoplastic Diseases and consisted of 150 female patients with breast cancer between 28 and 85 years old $(M=50.40)$. Evidences of content validity by expert judgment was found. Evidence of content validity was found by judges' criteria, and regarding the evidence of validity related to internal structure, the exploratory factor analysis (EFA) was employed. Regarding the results associated with the evidence of content validity, a $\mathrm{V}$ for Aiken was obtained for relevance $(V>.95)$ and clarity $(V>.85)$. Through the analytical-factorial procedure, 6 items $(1,2,4,6,7$ and 8) were eliminated for presenting factorial complexity (FC), and as a result, the total variance explained increased from $53.80 \%$ to $61.61 \%$. The final structure was conformed by three factors renamed as Body Perspective (F1), Sexual Interest (F2) and Pre-diagnostic and Peri-treatment Symptoms (F3). Finally, the reliability coefficients Alpha and Omega of the construct scores obtained adequate magnitudes (> .70) for the factors of Body Perspective (F1) and Pre-diagnostic and Peri-treatment Symptomatology (F3) with the exception of Sexual Interest (F2) which got an acceptable magnitude (> .65) while the ORION coefficient obtained a high magnitude (> .80) for all factors. In conclusion, favorable evidences of content validity and internal structure were determined for the QLQ-BR23 instrument.
\end{abstract}

Keywords: quality of life, breast cancer, QLQ-BR23, validity, reliability. 